\title{
Perbedaan Kemampuan Menulis Teks Prosedur Sebelum dan Sesudah Menggunakan Media Google Classroom Siswa Kelas XI SMA Negeri 6 Kota Bengkulu
}

\author{
Jon Kenedi \\ (corresponding author) \\ SMA Negeri 6 Kota Bengkulu \\ Email: Jonpasca01@gmail.com
}

\section{Gumono}

Program Studi Magister Pendidikan Bahasa Indonesia, Universitas Bengkulu Email: gumono@unib.ac.id

\section{Suryadi}

Program Studi Magister Pendidikan Bahasa Indonesia, Universitas Bengkulu Email: bklsuryadi@gmail.com

APA Citation: Kenedi, J., Gumono, G., \& Suryadi, S. (2021). Perbedaan Kemampuan Menulis Teks Prosedur Sebelum dan Sesudah Menggunakan Media Google Classroom Siswa Kelas XI SMA Negeri 6 Bengkulu. Silampari Bisa: Jurnal Penelitian Pendidikan Bahasa Indonesia, Daerah, dan Asing, 4(1), 181-196. https://doi.org/10.31540/silamparibisa.v4i1.1293

\begin{abstract}
Abstrak
Keterampilan menulis teks prosedur siswa masih rendah dikarenakan siswa belum memahami langkah-langkah menulis tek prosedur dan ciri bahasanya. Diterapkannya Google Classroom diprediksi akan mempengaruhi secara signifikan terhadap kemampuan menulis teks prosedur. Untuk iu, tujuan penelitian ini adalah mengetahui kemampuan menulis teks prosedur sebelum menggunakan media Google Classroom, mengetahui kemampuan menulis teks prosedur sesudah menggunakan media Google Classroom, dan mengetahui perbedaan kemampuan menulis teks prosedur sebelum dan sesudah menggunakan media Google Classroom siswa kelas XI SMA Negeri 6 Kota Bengkulu. Metode penelitian yang digunakan adalah metode eksperimen semu yaitu one group pre test-post test. Penelitian dilakukan di SMA Negeri 6 Kota Bengkulu pada bulan Oktober sampai dengan Desember 2020. Sampel yang diambil adalah siswa kelas XI IPS A tahun ajaran 2020/2021 berjumlah 35 siswa. Data dianalisis menggunakan uji hipotesis (uji-t). Hasil penelitian menunjukkan bahwa kemampuan menulis teks prosedur sebelum menggunakan Google Classroom sebesar 25,14 dengan kategori tinggi dan sesudah menggunakan Google Classroom sebesar 35,37 dengan kategori sangat tinggi. Berdasarkan hasil analisis uji t menyatakan bahwa terdapat perbedaan kemampuan menulis teks prosedur sebelum dan sesudah menggunakan media Google Classroom siswa kelas XI IPS SMA Negeri 6 Kota Bengkulu, dilihat nilai yang diperoleh pada signifikan (2-tailed) yaitu sebesar 0,00 dan terlihat nilai thitung lebih kecil yaitu $-20,858$ dari nilai t tabel sebesar -2.03 .
\end{abstract}

Kata kunci: perbedaan, kemampuan menulis teks prosedur, media Google Classroom 
Jon Kenedi, Gumono, Suryadi

Perbedaan Kemampuan Menulis Teks Prosedur Sebelum dan Sesudah Menggunakan Media

Google Classroom Siswa Kelas XI SMA Negeri 6 Bengkulu

\title{
Differences in the Ability to Write Procedural Texts Before and After Using Google Classroom Media for Class XI Students of SMA Negeri 6 Kota Bengkulu
}

\begin{abstract}
Students' writing procedural text skills are still low because students do not understand the steps of writing procedural text and its language characteristics. The implementation of Google Classroom is predicted to significantly affect the ability to write procedure text. For this reason, the purpose of this study was to determine the ability to write procedure texts before using Google Classroom media, to determine the ability to write procedure texts after using Google Classroom media, and to determine the differences in the ability to write procedure texts before and after using Google Classroom media for class XI students of SMA Negeri 6 Kota Bengkulu. The research method used is a quasi-experimental method, namely one group pre-test-post test. The research was conducted at SMA Negeri 6 Kota Bengkulu from October to December 2020. The samples taken were 35 students of class XI IPS A for the academic year 2020/2021. Data were analyzed using hypothesis testing ( $t$ test). The results showed that the ability to write procedure text before using Google Classroom was 25.14 in the high category and after using Google Classroom was 35.37 in the very high category. Based on the results of the t-test analysis, it states that there is a difference in the ability to write procedure texts before and after using Google Classroom media for class XI IPS students of SMA Negeri 6 Kota Bengkulu, seen the value obtained is significant (2-tailed) which is 0.00 and the t-count value is seen. smaller that is $-20,858$ than the $t$ table value of -2.03 .
\end{abstract}

Keywords: differences, ability to write procedure text, Google Classroom media

\section{A. Pendahuluan}

Google Classroom merupakan sebuah aplikasi yang mendukung terwujudnya ruang kelas di dunia maya. Aplikasi ini diasumsikan menjadi salah satu alternatif dalam menjawab persoalan dan tantangan pembelajaran di kelas. Selain itu, Google Classroom bisa menjadi sarana distribusi tugas, pengiriman tugas bahkan menilai tugas-tugas yang dikumpulkan, sehingga menciptakan pembelajaran yang aktif, efektif, efisien, dan menyenangkan (Pradana, 2017:60; Hikmatiar, 2020; Nafiah, 2020).

Google Classroom sebagai media pembelajaran dapat dikatakan unggul di dalam pembelajaran karena menjadi lebih efektif dan efisien, membuat proses pembelajaran menjadi lebih menarik, proses belajar siswa menjadi lebih interaktif dan kondusif, hemat waktu, motivasi belajar siswa dapat ditingkatkan, dan proses belajar dapat terjadi di mana saja dan kapan saja serta dapat meningkatkan kualitas belajar dengan baik (Soleh, 2021). Google Classroom yang digunakan dalam pembelajaran juga mampu meningkatkan motivasi belajar siswa dan mendorong peningkatan pada hasil belajar siswa (Hapsari \& Pamungkas, 2019). Google classroom sangat efektif digunakan dalam meningkatkan pembelajaran di tengah pandemi Covid-19 (Permata \& Bhakti, 2020). Google Classroom juga dapat memotivasi siswa dalam menulis teks eksplanasi (Nuryaningsih, 2021). Dengan demikian, pembelajaran dengan media Google Classroom dapat diterapkan pada semua mata pelajaran salah satunya adalah Mata Pelajaran Bahasa Indonesia.

Silampari Bisa: Jurnal Penelitian Pendidikan Bahasa Indonesia, Daerah, dan Asing Vol. 4, No. 1, 2021 
Pembelajaran pada Mata Pelajaran Bahasa Indonesia adalah belajar berkomunikasi, mengingat bahasa merupakan sarana komunikasi dalam masyarakat. Untuk dapat berkomunikasi dengan baik, seseorang perlu belajar cara berbahasa yang baik dan benar. Pembelajaran tersebut akan lebih baik jika dipelajari sejak dini dan secara berkesinambungan. Materi pembelajaran dalam bahasa Indonesia, salah satu materi pembelajarannya yaitu menulis teks prosedur.

Keterampilan menulis merupakan keterampilan berbahasa yang sulit penguasaannya karena menulis adalah kegiatan yang menuntut adanya latihan dan membutuhkan ketelitian serta kecerdasaan (Susetyo \& Noermanzah, 2020). Kegiatan menulis memerlukan pengetahuan yang luas dan pola pikir yang logis. Keterampilan menulis digunakan untuk mencatat, merekam, meyakinkan, melaporkan, menginformasikan, dan mempengaruhi pembaca (Amrolani dkk., 2014). Maksud dan tujuan seperti itu hanya dapat dicapai dengan baik oleh penulis yang memahami apa yang ditulisnya. Untuk itu, penulis perlu menggali pengetahuan mengenai topik yang akan ditulisnya (Tarigan, 2008:3-4). Menurut Nurgiyantoro (2012:439), terdapat beberapa indikator yang digunakan dalam penilaian menulis teks prosedur, yaitu: (1) kualitas isi tulisan, (2) keakuaratan isi tulisan, (3) organisasi penulisan teks prosedur, (4) kebermaknaan keseluruhan tulisan, (5) kosakata dan diksi, (6) ketepatan kalimat, (7) ejaan dan tata bahasa, serta (8) kelengkapan dan sumber rujukan.

Dari beberapa penelitian relevan oleh Soleh (2021), Hapsari \& Pamungkas (2019), Permata \& Bhakti (2020), dan Nuryaningsih (2021) menunjukkan bahwa Google Classroom belum diterapkan pada pembelajaran menulis teks prosedur. Menulis teks prosedur menurut Kosasih (2014:107) merupakan kegiatan menuangkan ide atau gagasan dengan menggunakan bahasa tulis sebagai media penyampaian dengan jenis teks yang berisi langkah-langkah yang harus ditempuh untuk mencapai tujuan yang diinginkan.

Berdasarkan observasi diperoleh informasi bahwa pada kelas XI SMA Negeri 6 Kota Bengkulu kemampuan menulis teks prosedur siswa masih rendah terlihat dari nilai yang diperoleh siswa pada tahun sebelumnya yang belum semuanya mencapai nilai KKM. Dengan digunakannya media Google Classroom diprediksi akan mempengaruhi secara signifikan terhadap kemampuan menulis teks prosedur. Berdasarkan latar belakang tersebut, penulis tertarik untuk membuktikan hipotesis "Ada perbedaan kemampuan menulis teks prosedur sebelum dan sesudah menggunakan media Google Classroom siswa kelas XI SMA Negeri 6 Kota Bengkulu".

\section{B. Metode Penelitian}

Metode yang digunakan dalam penelitian ini adalah metode eksperimen semu. Desain eksperimen yang digunakan yaitu one group pre test-post test. Desain ini memperlihatkan perbedaan sebelum (pre test) dan sesudah (post test) perlakuan (treatment) diberikan.

Populasi dalam penelitian ini adalah siswa kelas XI (Sebelas) SMA Negeri 6 Kota Bengkulu semester ganjil tahun 2020/2021. Sedangkan sampel penelitian yang diambil adalah siswa kelas XI IPS A tahun ajaran 2020/2021 berujumlah 35 siswa. Pemilihan sampel ini menggunakan metode purposive sampling dengan tujuan melihat satu kelas penuh sebagai kelas sampel. 


\section{Jon Kenedi, Gumono, Suryadi}

Perbedaan Kemampuan Menulis Teks Prosedur Sebelum dan Sesudah Menggunakan Media Google Classroom Siswa Kelas XI SMA Negeri 6 Bengkulu

Teknik pengumpulan data menggunakan tes. Instrumen tes yang digunakan adalah soal uraian yang dilaksanakan pada saat pra tindakan maupun pada akhir tindakan, yang nantinya hasil tes ini akan diolah untuk mengetahui tingkat keberhasilan siswa dalam proses pembelajaran yang menerapkan aplikasi Google Classroom pada Mata Pelajaran Bahasa Indonesia. Instrumen tes ini sudah diujikan dan hasilnya valid dan reabel sehingga siap digunakan dalam kegiatan pre test dan post test. Untuk kisi-kisi kemampuan tes kognitif dapat dilihat pada tabel berikut.

Tabel 1. Kisi-Kisi Kemampuan Menulis Teks Prosedur

\begin{tabular}{|c|c|c|c|}
\hline No & $\begin{array}{l}\text { Aspek yang } \\
\text { dinilai }\end{array}$ & Indikator & Skor \\
\hline \multirow[t]{5}{*}{1} & \multirow[t]{5}{*}{$\begin{array}{l}\text { Kualitas } \quad \text { Isi } \\
\text { Tulisan }\end{array}$} & $\begin{array}{l}\text { Menguasai topk tulisan, substantif, jelas dalam isi } \\
\text { tulisan. }\end{array}$ & 5 \\
\hline & & $\begin{array}{l}\text { Menguasai permasalahan, memadai tetapi kurang } \\
\text { terperinci. }\end{array}$ & 4 \\
\hline & & $\begin{array}{l}\text { Penguasaan permasalahan terbatas, substansi } \\
\text { kurang, pengembangan topik kurang. }\end{array}$ & 3 \\
\hline & & Kurang menguasai permasalahan tidak ada substansi. & 2 \\
\hline & & Kurang menguasai permasalahan, kurang layak dinilai. & 1 \\
\hline \multirow[t]{5}{*}{2} & \multirow[t]{5}{*}{$\begin{array}{l}\text { Keakuratan } \\
\text { tulisan }\end{array}$} & $\begin{array}{l}\text { Isi tulisan sangat tepat, pengembangan topik sangat } \\
\text { tepat, relevan dengan topik yang dibahas. }\end{array}$ & 5 \\
\hline & & $\begin{array}{l}\text { Isi tulisan sangat tepat, pengembangan topik terbatas, } \\
\text { relevan dengan topik. }\end{array}$ & 4 \\
\hline & & $\begin{array}{l}\text { Isi tulisan memadai, pengembangan topik tidak } \\
\text { memadai, kurang relevan dengan topik. }\end{array}$ & 3 \\
\hline & & Isi tulisan memadai tetapi tidak relevan dengan topik. & 2 \\
\hline & & Isi tulisan tidak memadai, tidak relevan dengan topik. & 1 \\
\hline \multirow[t]{5}{*}{3} & \multirow{5}{*}{$\begin{array}{l}\text { Organisasi } \\
\text { penulisan } \\
\text { prosedur }\end{array}$} & $\begin{array}{l}\text { Gagasan terungkap padat dengan jelas, tertata } \\
\text { dengan baik, urutan logis dan kohesif. }\end{array}$ & 5 \\
\hline & & $\begin{array}{l}\text { Kurang terorganisasi, tetapi ide utama ternyatakan, } \\
\text { pendukung terbatas, logis, tetapi tidak lengkap. }\end{array}$ & 4 \\
\hline & & $\begin{array}{l}\text { Gagasan kacau atau kurang terkait, urutan dan } \\
\text { pengembangan kurang logis. }\end{array}$ & 3 \\
\hline & & Kurang komunikatif, kurang terorganisasi. & 2 \\
\hline & & Sangat tidak terorganisasi, kurang layak dinilai. & 1 \\
\hline \multirow[t]{5}{*}{4} & \multirow[t]{5}{*}{$\begin{array}{l}\text { Kebermaknaan } \\
\text { keseluruhan } \\
\text { tulisan }\end{array}$} & $\begin{array}{l}\text { Menguasai aturan penulisan, tulisan terbaca, terdapat } \\
\text { sedikit kesalahan ejaan, tetapi tidak mengurangi } \\
\text { makna. }\end{array}$ & 5 \\
\hline & & $\begin{array}{l}\text { Tulisan terbaca, sebagian tulisan terjadi kesalahan } \\
\text { ejaan, tetapi tidak mengurangi makna. }\end{array}$ & 4 \\
\hline & & $\begin{array}{l}\text { Tulisan terbaca, terjadi kesalahan ejaan dan makna } \\
\text { membingungkan. }\end{array}$ & 3 \\
\hline & & $\begin{array}{l}\text { Tidak menguasai aturan penulisan, tulisan kurang } \\
\text { terbaca, terdapat banyak kesalahan ejaan. }\end{array}$ & 2 \\
\hline & & Tidak menguasai aturan penulisan, tidak layak dinilai. & 1 \\
\hline \multirow[t]{2}{*}{5} & \multirow[t]{2}{*}{$\begin{array}{l}\text { Kosakata } \\
\text { diksi }\end{array}$} & $\begin{array}{l}\text { Penguasaan kata luas, piihan kata dan ungkapan } \\
\text { efektif, menguasai pembentukan kata, penggunaan } \\
\text { register tepat. }\end{array}$ & 5 \\
\hline & & $\begin{array}{l}\text { Penguasaan kata memadai, pilihan, bentuk dan } \\
\text { penggunaan kata/ungkapan sebagian salah tetapi } \\
\text { tidak menggunggu. }\end{array}$ & 4 \\
\hline
\end{tabular}

Silampari Bisa: Jurnal Penelitian Pendidikan Bahasa Indonesia, Daerah, dan Asing Vol. 4, No. 1, 2021 


\begin{tabular}{|c|c|c|c|}
\hline & & $\begin{array}{l}\text { Penguasaan kata terbatas, sering terjadi kesalahan } \\
\text { bentuk, pilihan dan penggunaan kosakata/ungkapan } \\
\text { makna membingungkan atau kurang jelas. }\end{array}$ & 3 \\
\hline & & $\begin{array}{l}\text { Pengetahuan tentang kosakata, ungkapan dan } \\
\text { pembentukan kata rendah. }\end{array}$ & 2 \\
\hline & & $\begin{array}{l}\text { Penguasaan kata sangat terbatas, ungkapan dan } \\
\text { pembentukan kata rendah dan kurang layak nilai. }\end{array}$ & 1 \\
\hline \multirow[t]{5}{*}{6} & \multirow[t]{5}{*}{$\begin{array}{l}\text { Ketepatan } \\
\text { Kalimat }\end{array}$} & $\begin{array}{l}\text { Konstruksi kompleks dan efektif, hanya sedikit } \\
\text { kesalahan penggunaan bahasa. }\end{array}$ & 5 \\
\hline & & $\begin{array}{l}\text { Konstruksi sederhana tetapi efektif, terdapat kesalahan } \\
\text { kecil pada konstruksi komplek, terjadi sejumlah } \\
\text { kesalahan penggunaan bahasa, tetapi makna cukup } \\
\text { jelas. }\end{array}$ & 4 \\
\hline & & $\begin{array}{l}\text { Terjadi kesalahan serius dalam konstruksi kalimat } \\
\text { tunggal atau kompleks, makna membingungkan atau } \\
\text { kabur. }\end{array}$ & 3 \\
\hline & & $\begin{array}{l}\text { Kurang menguasai tata kalimat, terdapat banyak } \\
\text { kesalahan. }\end{array}$ & 2 \\
\hline & & $\begin{array}{l}\text { Terjadi banyak kesalahan, kurang komunikatif, dan } \\
\text { kurang layak teliti. }\end{array}$ & 1 \\
\hline \multirow[t]{5}{*}{7} & \multirow[t]{5}{*}{$\begin{array}{l}\text { Ejaan dan Tata } \\
\text { Tulis }\end{array}$} & $\begin{array}{l}\text { Menguasai aturan penulisan, terdapat sedikit } \\
\text { kesalahan ejaan, tanda baca, dan penggunaan huruf } \\
\text { kapital. }\end{array}$ & 5 \\
\hline & & $\begin{array}{l}\text { Sebagian terjadi kesalahan ejaan, tanda baca, } \\
\text { penggunaan huruf capital, dan paragraf, tetapi tidak } \\
\text { mengurangi makna. }\end{array}$ & 4 \\
\hline & & $\begin{array}{l}\text { Sering terjadi kesalahan ejaan, tanda baca, } \\
\text { penggunaan huruf capital dan penataan paragraf, } \\
\text { tulisantangan kurang jelas, makna membingungkan. }\end{array}$ & 3 \\
\hline & & $\begin{array}{l}\text { Kurang menguasai aturan penulisan, terdapat banyak } \\
\text { kesalahan ejaan, tanda baca, penggunaan huruf } \\
\text { capital, dan penataan paragraf, tulisan kurang terbaca. }\end{array}$ & 2 \\
\hline & & $\begin{array}{l}\text { Kurang menguasai aturan penulisan dan kurang layak } \\
\text { dinilai }\end{array}$ & 1 \\
\hline \multirow[t]{5}{*}{8} & \multirow[t]{5}{*}{$\begin{array}{l}\text { Kelengkapan dan } \\
\text { Sumber Rujukan }\end{array}$} & $\begin{array}{l}\text { Sumber rujukan komplek, hanya sedikit kesalahan } \\
\text { penggunaan tanda baca. }\end{array}$ & 5 \\
\hline & & $\begin{array}{l}\text { Sumber rujukan sedikit, dan terdapat kesalahan kecil } \\
\text { pada sumber rujukan, terjadi sejumlah kesalahan } \\
\text { penggunaan tanda baca. }\end{array}$ & 4 \\
\hline & & $\begin{array}{l}\text { Sumber rujukan sebagian terjadi } \\
\text { membingungkan atau kabur. }\end{array}$ & 3 \\
\hline & & Sumber rujukan terdapat banyak kesalahan. & 2 \\
\hline & & $\begin{array}{l}\text { Terjadi kesalahan serius dalam sumber rujukan kurang } \\
\text { layak dinilai. }\end{array}$ & 1 \\
\hline
\end{tabular}

Sumber: Nurgiyantoro (2012)

Teknik analisis data yang digunakan dengan langkah-langkah berikut: 1) melakukan uji normalitas data menggunakan uji Kolmogorov-Smirnov dan SPSS 16 , 2) melakukan uji homogenitas menggunakan uji $F$ atu uji variansi dan menggunakan SPSS 16, 3) uji hipotesis dengan uji t dan menggunakan SPSS 16 dengan cara membandingkan t hitung dengan t tabel pada tingkat signifikan $5 \%$. Jika $t$ hitung $>\mathrm{t}$ tabel maka variabel bebas dapat menerangkan terikatnya, dan artinya ada 
Jon Kenedi, Gumono, Suryadi

Perbedaan Kemampuan Menulis Teks Prosedur Sebelum dan Sesudah Menggunakan Media Google Classroom Siswa Kelas XI SMA Negeri 6 Bengkulu

pengaruh antara variabel bebas dengan variabel terikatnya. Kriteria pengujiannya adalah sebagai berikut:

a. Jika $t_{\text {hitung }}>t_{\text {tabel, }}$, atau $-t_{\text {hitung }}<-t_{\text {tabel }}$ maka tolak Ho dan terima Ha, artinya secara individu variabel bebas berpengaruh terhadap variabel terikat.

b. Jika $t_{\text {hitung }}<t_{\text {tabel }}$, atau $-t_{\text {hitung }}>-t_{\text {tabel }}$ maka terima Ho dan tolak Ha, artinya secara individu variabel bebas tidak berpengaruh terhadap variabel terikat.

\section{Hasil Penelitian dan Pembahasan}

1. Hasil Penelitian

a. Kemampuan Menulis Teks Prosedur Siswa Sebelum Menggunakan Media Google Clasroom

Pada penelitian ini data hasil belajar Google Classroom yang dimaksud adalah data yang digunakan pada saat pre test yaitu dengan menggunakan soal essay. Dalam penelitian ini penulis menggunakan metode eksperimen semu (quasi experiment) dengan desain penelitian berupa one group pre test-post test. Desain penelitian one group pre test-post test terhadap satu kelas yaitu kelas XI IPS A sebagai subyek penelitian dengan melihat perbedaan sebelum dan sesudah perlakuan (treatment) diberikan yaitu Google Classroom. Pada saat sebelum menggunakan media Google Classroom diketahui bahwa jumlah siswa kelas XI IPS A berjumlah 35 siswa. Penelitian dilakukan dengan langkah-langkah:

1. Peneliti mengajak siswa untuk berdoa sesuai Agama dan kepercayaan masing-masing,

2. Peneliti mencek daftar hadir.

3. Peneliti mereviu kembali materi sebelumnya,

4. Peneliti menyampaikan semua tujuan pelajaran yang ingin dicapai pada pelajaran tersebut dan memotivasi siswa belajar.

5. Peneliti melakukan pre test dengan soal atau pertanyaan mengenai "Menulis Teks Prosedur". Tema yang disediakan guru tersebut adalah:

1) Cara Membersihkan Tangan yang Benar pada Masa Pandemi Covid-19;

2) Cara Menghidupkan dan Mematikan Komputer;

3) Cara Membuat Jus Mangga Bengkulu;

4) Cara Membuat Sup Ayam Burgo; dan

5) Cara Membuat Nasi Goreng Ikan Teri.

Untuk "Menulis Teks Prosedur" dengan indikator yang digunakan dalam penilaian menulis teks prosedur menurut Nurgiyantoro (2012: 439) yaitu: 1) kualitas isi tulisan, 2) keakuratan isi tulisan, 3) organisasi penulisan teks prosedur, 4) kebermaknaan keseluruhan tulisan, 5) kosakata dan diksi, 6) ketepatan kalimat, 7) ejaan dan tata tulis, serta 8) kelengkapan dan sumber rujukan. Karena data tersebut merupakan data kualitatif maka dibuat skor untuk menentukan tingkat capaian 1, 2, 3, 4 dan 5 . Selanjutnya dibuat tabulasi pre test (sebelum) berdasarkan indikator menulis teks prosedur tersebut.

Untuk melihat kemampuan menulis teks prosedur siswa sebelum menggunakan Google Clasroom lebih jelas dapat dilihat pada tabel 2 berikut.

Silampari Bisa: Jurnal Penelitian Pendidikan Bahasa Indonesia, Daerah, dan Asing Vol. 4, No. 1, 2021 
Jon Kenedi, Gumono, Suryadi

Perbedaan Kemampuan Menulis Teks Prosedur Sebelum dan Sesudah Menggunakan Media Google Classroom Siswa Kelas XI SMA Negeri 6 Bengkulu

Tabel 2. Tingkat Kemampuan Menulis Teks Prosedur Sebelum Menggunakan Media Google Classroom

\begin{tabular}{lcc}
\hline \multirow{2}{*}{ Keterangan } & \multicolumn{2}{c}{$\begin{array}{c}\text { Kemampuan Menulis Teks Prosedur Sebelum } \\
\text { Menggunakan Google Clasroom }\end{array}$} \\
\cline { 2 - 2 } & Kelas XI IPS A & Kategori \\
\hline Jumlah & 880 & \\
\hline Skor tertinggi & 32 & Tinggi \\
\hline Skor terendah & 19 & \\
\hline Rata-rata & 25,14 & \\
\hline
\end{tabular}

Berdasarkan tabel 2 di atas diketahui bahwa rata-rata kemampuan menulis teks prosedur pada saat sebelum menggunakan Google Classroom di kelas XI IPS A yaitu sebesar 25,14 dengan kategori tinggi, skor tertinggi 32 dan nilai yang terendah 19.

\section{b. Kemampuan Menulis Teks Prosedur Siswa Sesudah Menggunakan Media Google Clasroom}

Pada penelitian ini sesudah menggunakan Google Classroom yang telah dilakukan bahwa kelas XI IPS A yang berjumlah 35 siswa. Penelitian dilakukan dengan langkah-langkah:

1. Peneliti memberikan penjelasan kepada peserta didik tentang "Menulis Teks Prosedur".

2. Peneliti memberikan kesempatan kepada peserta didik untuk bertanya atau menyampaikan pendapat.

3. Peneliti melakukan post test dengan soal atau pertanyaan mengenai "Menulis Teks Prosedur" dengan cara guru mengklik tanda $(+)$ pada tab dan meminta siswa untuk menentukan tema umum atau topik karangan di Google Classroom dan siswa mengunduh dan memilih tema umum atau topik karangan dan mengirim di Google Classroom.

4. Tema yang disediakan guru tersebut adalah:

1) Cara Membersihkan Tangan yang Benar pada Masa Pandemi Covid-19;

2) Cara Menghidupkan dan Mematikan Komputer;

3) Cara Membuat Jus Mangga Bengkulu;

4) Cara Membuat Sup Ayam Burgo; dan

5) Cara Membuat Nasi Goreng Ikan Teri.

Untuk "Menulis Teks Prosedur" dengan indikator yang digunakan dalam penilaian menulis teks prosedur menurut Nurgiyantoro (2012:439) yaitu : 1) kualitas isi tulisan, 2) keakuratan isi tulisan, 3) organisasi penulisan teks prosedur, 4) kebermaknaan keseluruhan tulisan, 5) kosakata dan diksi, 6) ketepatan kalimat, 7) ejaan dan tata tulis, serta 8) kelengkapan dan sumber rujukan. Oleh karena data tersebut merupakan data kualitatif maka dibuat skor untuk menentukan tingkat capaian 1, 2, 3, 4 dan 5. Selanjutnya dibuat tabulasi post test (sesudah) berdasarkan indikator menulis teks prosedur tersebut.

Untuk melihat kemampuan menulis teks prosedur siswa sesudah menggunakan Google Classroom lebih jelas dapat dilihat pada tabel 3 di bawah ini. 
Jon Kenedi, Gumono, Suryadi

Perbedaan Kemampuan Menulis Teks Prosedur Sebelum dan Sesudah Menggunakan Media Google Classroom Siswa Kelas XI SMA Negeri 6 Bengkulu

Tabel 3. Tingkat Kemampuan Menulis Teks Prosedur Sesudah Menggunakan Media Google Clasroom

\begin{tabular}{lcc}
\hline \multirow{2}{*}{ Keterangan } & \multicolumn{2}{c}{ Hasil Post test } \\
\cline { 2 - 2 } & Kelas XI IPS A & Kategori \\
\hline Jumlah & 1238 & \multirow{2}{*}{ Sangat Tinggi } \\
\hline Skor Tertinggi & 40 & \\
\hline Skor Terendah & 30 & \\
\hline Rata-Rata & 35,37 & \\
\hline
\end{tabular}

Berdasarkan tabel 3 di atas diketahui bahwa rata-rata kemampuan menulis teks prosedur pada saat sesudah menggunakan Google Classroom yaitu sebesar 35,37 dengan kategori tinggi, skor tertinggi 40, dan yang terendah 30 .

\section{c. Perbedaan Kemampuan Menulis Teks Prosedur Siswa Sebelum dan Sesudah Menggunakan Media Google Clasroom}

Sebelum menguji data utama maka perlu di uji terlebih dahulu uji normalitas dan uji homogenitas yaitu:

1) Uji Normalitas

Untuk mengetahui apakah data atau hasil penelitian yang telah kita lakukan tersebut sudah normal atau tidak maka pelu dilakukan uji normalitas menggunakan Kolmogorov-Smirnov test dengan SPSS 16. Untuk melihat hasil uji normalitas pada siswa kelas XI IPS A di SMA Negeri 6 Kota Bengkulu dapat dilihat pada tabel 4 di bawah ini.

Tabel 4. One-Sample Kolmogorov-Smirnov Test

\begin{tabular}{|ll|r|r|}
\hline & & Pretest & Posttest \\
\hline N & & 35 & 35 \\
Normal Parameters & Mean & 25.14 & 35.37 \\
& Std. Deviation & 3.246 & 2.365 \\
Most Extreme & Absolute & .123 & .134 \\
Differences & Positive & .123 & .134 \\
& Negative & -.059 & -.126 \\
Kolmogorov-Smirnov Z & .730 & .792 \\
Asymp. Sig. (2-tailed) & .662 & .558 \\
\hline
\end{tabular}

a. Test distribution is Normal.

Keterangan:

1. Jika nilai sig. (2-tailed) $>0,05$, maka nilai residual berdistribusi normal.

2. Jika nilai sig. (2-tailed) $<0,05$, maka nilai residual tidak berdistribusi normal.

Berdasarkan tabel 4 di atas diketahui bahwa kemampuan menulis teks prosedur pada saat sebelum menggunakan Google Classroom dan pada saat sesudah menggunakan Google Classroom (post test) pada siswa kelas XI IPS A di SMA Negeri 6 Kota Bengkulu adalah berdistribusi normal. Hal ini dapat dilihat bahwa nilai yang diperoleh pada signifikan (2-tailed) yaitu sebelum menggunakan Google Classroom 0,662 dan sesudah menggunakan Google Classroom 0,558 yang lebih besar dari ketentuan uji statistic One-Sample Kolmogorov-Smirnov Test yaitu 0,05, 
Jon Kenedi, Gumono, Suryadi

Perbedaan Kemampuan Menulis Teks Prosedur Sebelum dan Sesudah Menggunakan Media Google Classroom Siswa Kelas XI SMA Negeri 6 Bengkulu

jadi 0,662 >0,05 dan 0,558 > 0,05 yang berarti menunjukan data berdistribusi normal. Hal ini menunjukkan bahwa nilai kemampuan menulis teks prosedur sebelum dan sesudah menggunakan Google Classroom berdistribusi normal. Langkah-langkah uji normalitas pada SPSS tersebut sebagai berikut.

1. Buka File SPSS.

2. Lihat pada Variabel View.

3. Selanjutnya lihat/aktifkan Data View.

4. Klik Analyze--> Nonparametric test--> Sampel K-AS, dan masukkan Variabel ke dalam Kotak Test Variable List.

5. Klik option, lihat pada bagian Descriptive, kemudian Aktifkan/Klik/Pilih Continue.

6. Klik/Pilih Normal.

7. Klik OK, dan lihat Hasil Output SPSS-nya.

8. Kemudian Simpan File Output SPSS tersebut dengan nama: Output Normalitas.

2) Uji Homogenitas

Uji homogenitas dilakukan apabila data penelitian telah diketahui berdistribusi normal, kemudian dilanjukan dengan uji homogenitas varian dengan uji Levene Statistic. Untuk mengetahui hasil uji homogenitas varian data pretest dapat dilihat pada tabel 5 di bawah ini.

Tabel 5. Test of Homogeneity of Variances

Kemampuan menulis teks prosedur

\begin{tabular}{|c|c|c|c|}
\hline Levene Statistic & df1 & df2 & Sig. \\
\hline 3.327 & 1 & 68 & .073 \\
\hline
\end{tabular}

Keterangan:

1. Jika nilai signifikansi $>0,05$, maka distribusi data adalah homogen.

2. Jika nilai signifikansi $<0,05$, maka, maka distribusi data adalah tidak homogen.

Berdasarkan tabel 5 di atas diketahui bahwa kemampuan menulis teks prosedur sebelum dan sesudah menggunakan media Google Classroom pada siswa kelas XI IPS A di SMA Negeri 6 Kota Bengkulu adalah memiliki varian yang homogeny. Hal ini dapat dilihat bahwa nilai yang diperoleh pada signifikan sebesar 0,073 yang lebih besar dari ketentuan uji statistic Test of Homogeneity of Variances yaitu 0,05. Jadi $0,732>0,05$ yang berarti menunjukkan data kemampuan menulis teks prosedur siswa pada pre test dan post test mempunyai varian yang homogen.

Untuk menguji kehomogenan data sampel berdasarkan pengelompokkan data, lakukan langkah-langkah berikut ini:

1. Buka File SPSS.

2. Lihat pada variabel view.

3. Selanjutnya pada value buat kode untuk pre test yaitu 1 dan post test dengan kode 2 .

4. Klik Analyze--> Compare Means--> One way anova, dan masukkan Variabel ke dalam Kotak Dependent List untuk variable $Y$ dan variable $X$ ke kotak Factor. 


\section{Jon Kenedi, Gumono, Suryadi}

Perbedaan Kemampuan Menulis Teks Prosedur Sebelum dan Sesudah Menggunakan Media Google Classroom Siswa Kelas XI SMA Negeri 6 Bengkulu

5. Klik option, klik homogeinity of varian test, kemudian Aktifkan/Klik/Pilih continue.

6. Klik OK, dan lihat Hasil Output SPSS-nya.

7. Kemudian Simpan File Output SPSS tersebut dengan nama: Output Homogenitas.

Setelah data penelitian telah diketahui mempunyai distribusi normalitas, kemudian dilanjukan dengan uji $\mathrm{t}$ dengan Paired Samples Correlations yang digunakan untuk melihat data penelitian apakah sudah berbeda signifikan atau belum pada saat sebelum menggunakan Google Classroom (pre test) dan pada saat setelah menggunakan Google Classroom (post test) pada siswa kelas XI IPS A di SMA Negeri 6 Kota Bengkulu. Untuk mengetahui hasil uji t dapat dilihat pada tabel 6 dan tabel 7 berikut.

Tabel 6. Paired Samples Correlations

\begin{tabular}{|lr|r|r|r|}
\hline & $\mathrm{N}$ & Correlation & \multicolumn{1}{|c|}{ Sig. } \\
\hline Pair 1 Pretest \& Posttest & 35 & .502 & .002 \\
\hline
\end{tabular}

Tabel 7. Paired Samples Test

\begin{tabular}{|c|c|c|c|c|c|c|c|c|}
\hline & \multicolumn{5}{|c|}{ Paired Differences } & \multirow[b]{3}{*}{$\mathrm{t}$} & \multirow[b]{3}{*}{$d f$} & \multirow{3}{*}{$\begin{array}{c}\text { Sig. } \\
\text { (2-tailed) }\end{array}$} \\
\hline & \multirow[b]{2}{*}{ Mean } & \multirow{2}{*}{$\begin{array}{c}\text { Std. } \\
\text { Deviation }\end{array}$} & \multirow{2}{*}{$\begin{array}{c}\text { Std. Error } \\
\text { Mean }\end{array}$} & \multicolumn{2}{|c|}{$\begin{array}{l}95 \% \text { Confidence } \\
\text { Interval of the } \\
\text { Difference }\end{array}$} & & & \\
\hline & & & & Lower & Upper & & & \\
\hline $\begin{array}{ll}\text { Pair } & \text { Pretest - } \\
1 & \text { Posttest }\end{array}$ & -10.229 & 2.901 & .490 & -11.225 & -9.232 & -20.858 & 34 & .000 \\
\hline
\end{tabular}

\section{Keterangan:}

1. Jika nilai sig. (2-tailed) $<0,05$, maka terdapat perbedaan yang signifikan antara kemampuan menulis teks prosedur antara sebelum dan sesudah menggunakan Google Clasroom.

2. Jika nilai sig. (2-tailed) $>0,05$, maka tidak terdapat perbedaan yang signifikan antara kemampuan menulis teks prosedur antara sebelum dan sesudah menggunakan Google Clasroom.

Berdasarkan tabel 7 di atas diketahui bahwa terdapat perbedaan yang signifikan antara kemampuan menulis teks prosedur antara sebelum dan sesudah menggunakan Google Classroom di SMA Negeri 6 Kota Bengkulu. Hal ini dapat dilihat bahwa nilai yang diperoleh pada signifikan (2-tailed) yaitu sebesar 0,00 yang lebih kecil dari ketentuan uji statistic Paired Samples Correlations yaitu 0,05. Jadi $0,00<0,05$ yang berarti menunjukkan data terdapat perbedaan yang signifikan, artinya bahwa pembelajaran Google Classroom berpengaruh terhadap hasil belajar siswa kelas XI IPS A di SMA Negeri 6 Kota Bengkulu.

Untuk melihat perbedaan antara sebelum dan sesudah mrnggunakan Google Classroom maka dapat dilihat pada tabel berikut. 
Jon Kenedi, Gumono, Suryadi

Perbedaan Kemampuan Menulis Teks Prosedur Sebelum dan Sesudah Menggunakan Media Google Classroom Siswa Kelas XI SMA Negeri 6 Bengkulu

Tabel 8. Data Kemampuan Menulis Teks Prosedur Siswa Sebelum dan Sesudah Menggunakan Media Google Classroom

\begin{tabular}{|c|c|c|c|}
\hline No. & Nama Siswa & Sebelum & Sesudah \\
\hline 1. & Afifah Mardiana & 32 & 39 \\
\hline 2. & Aisyah Mawarni & 27 & 34 \\
\hline 3. & Aldiansyah & 26 & 35 \\
\hline 4. & Andiko Saputra & 24 & 36 \\
\hline 5. & Anisa Mutiara Siregar & 25 & 40 \\
\hline 6. & Della Finata Dwi Putri & 26 & 38 \\
\hline 7. & Diah Indah Sonarti & 27 & 35 \\
\hline 8. & Dicky Gema Saputra & 27 & 35 \\
\hline 9. & Dinda Latifa Mafuzah & 29 & 37 \\
\hline 10. & Dwi Falinsa & 24 & 32 \\
\hline 11. & Gilang Rizki Maulana & 25 & 35 \\
\hline 12. & Giovani & 26 & 34 \\
\hline 13. & Herlina & 21 & 30 \\
\hline 14. & Ikhsan Setyawan & 24 & 38 \\
\hline 15. & Inayah Dewi Salsabila & 29 & 37 \\
\hline 16. & Jeni Rahmatika & 27 & 38 \\
\hline 17. & Jibran Syaputra & 24 & 32 \\
\hline 18. & Jimmy Syaputra & 22 & 38 \\
\hline 19. & Jonathan Rolanda & 23 & 33 \\
\hline 20. & Muhammad Ardian & 23 & 35 \\
\hline 21. & Mutiara Citra & 22 & 33 \\
\hline 22. & Nur Aisyah Novia R & 20 & 37 \\
\hline 23. & Nurkalishah Berliani & 21 & 34 \\
\hline 24. & Okti Dwi Elsa putri & 25 & 33 \\
\hline 25. & Patra Virgian & 29 & 35 \\
\hline 26. & Rabillah Laras Ayu & 22 & 35 \\
\hline 27. & Rahma Nisyah & 19 & 31 \\
\hline 28. & Rahma Safitri Harahap & 23 & 35 \\
\hline 29. & Rasti permata Sari & 23 & 37 \\
\hline 30. & Rizky Anugerah P & 23 & 33 \\
\hline 31. & Salsabila & 32 & 38 \\
\hline 32. & Septa Dia Perdana & 31 & 37 \\
\hline 33. & Shafa Cha-Cha K & 28 & 36 \\
\hline 34. & Tasyiah Nurhikmah & 27 & 38 \\
\hline 35. & Yili Yanti & 24 & 35 \\
\hline \multicolumn{2}{|c|}{ Jumlah } & 880 & 1238 \\
\hline \multicolumn{2}{|c|}{ Rata-rata } & 25.14 & 35.3714 \\
\hline
\end{tabular}

Langkah-langkah uji t dengan SPSS tersebut adalah:

1. Buka File SPSS.

2. Isikan data variabel sesuai dengan data yang diperlukan.

3. Isilah data pada Data View sesuai dengan data yang diperoleh.

4. Untuk menjalankan prosedur ini adalah dari menu kemudian pilih Analyze Compare Means - One Sample T Test.

5. Masukkan variable Capaian pada kotak Test Variable dan pada kotak Test Value.

6. Klik Option sehingga muncul kotak dialog. Isi $95 \%$ pada condifent interval dan pilih Exlude Cases Analysis By Analysis, klik Continue, lalu Ok .

Silampari Bisa: Jurnal Penelitian Pendidikan Bahasa Indonesia, Daerah, dan Asing Vol. 4, No. 1, 2021 
Jon Kenedi, Gumono, Suryadi

Perbedaan Kemampuan Menulis Teks Prosedur Sebelum dan Sesudah Menggunakan Media Google Classroom Siswa Kelas XI SMA Negeri 6 Bengkulu

7. Lihat Hasil Output SPSS-nya.

8. Kemudian Simpan File Output SPSS tersebut dengan nama Output Normalitas.

\section{Pembahasan}

Berdasarkan hasil penelitian yang telah dilakukan di kelas XI IPS A SMA Negeri 6 Kota Bengkulu diketahui bahwa hasil penelitian terdapat perbedaan kemampuan menulis teks prosedur siswa sebelum dan sesudah menggunakan media Google Classroom. Dari data tes kemampuan menulis teks prosedur sebelum diterapkannya pembelajaran dengan menggunakan media Google Classroom dengan kategori tinggi dimana hasil rata-rata kemampuan menulis teks prosedur siswa 25,14. Setelah dilakukannya model pembelajaran dengan media Google Classroom terdapat nilai rata-rata kemampuan menulis teks prosedur siswa sebesar 35,37 dengan kategori sangat tinggi. Berdasarkan hasil penelitian ini terdapat peningkatan kemampuan menulis teks prosedur, dan dinyatakan rata-rata semua siswa memiliki kemampuan menulis teks prosedur.

Penelitian ini sejalan dengan penelitian Ernawati (2018) bahwa penggunaan Google Classroom terdapat perbedaan atau berpengaruh positif terhadap kualitas pembelajaran pada Mata Pelajaran Bahasa Indonesia kelas XI di MAN 1 Kota Tangerang Selatan. Hal ini ditunjukan dengan nilai yang diperoleh nilai thitung $2.847, \mathrm{t}$ hitung $>\mathrm{t}$ Tabel $(2,357>2,045)$ dengan siginifikansi 0.025 (pengujian dua sisi). Dengan demikian, semakin baik penggunaan Google Classroom maka akan semakin baik kualitas pembelajaran yang ada di kelas pada Mata Pelajaran Ekonomi kelas XI di MAN 1 Kota Tangerang Selatan. Penggunaan Google Classroom terdapat perbedaan atau berpengaruh positif terhadap hasil belajar siswa pada Mata Pelajaran Bahasa Indonesia kelas XI di MAN 1 Kota Tangerang Selatan, dengan demikian semakin baik penggunaan Google Classroom maka akan semakin baik kualitas pembelajaran yang ada di kelas dan semakin baik pula hasil belajar siswa pada Mata Pelajaran Ekonomi kelas XI di MAN 1 Kota Tangerang Selatan.

Berdasarkan informasi dari siswa kelas XI IPS A di SMA N 6 Kota Bengkulu bahwa dengan pembelajaran Google Classroom sangat efektif, mudah untuk dimengerti, materinya rinci, ditambah dengan contoh video dan gambar sehingga lebih memudahkan dalam memahami materi, bisa belajar kapanpun dan di manapun, dan tidak banyak biaya yang dikeluarkan. Rata-rata kemampuan menulis teks prosedur siswa kelas XI IPS A di SMA Negeri 6 Kota Bengkulu sebelum menggunakan media Google Classroom yaitu sebesar 25,14 atau dengan kategori tinggi, dengan skor tertinggi 32 dan nilai yang terendah 19. Selanjutnya rata-rata kemampuan menulis teks prosedur siswa sesudah menggunakan media Google Classroom yaitu sebesar 35,37 atau dengan kategori tinggi, dengan skor tertinggi 40 dan nilai yang terendah 30 . Jadi dapat disimpulkan bahwa skor rata-rata kemampuan menulis teks prosedur siswa lebih tinggi sesudah menggunakan model pembelajaran Google Classroom dibandingkan dengan rata-rata menulis teks prosedur siswa sebelum atau tidak menggunakan media Google Classroom.

Hal ini berdasarkan informasi dan wawancara dari siswa kelas XI IPS A di SMA Negeri 6 Kota Bengkulu dengan menggunakan media Google Classroom memberikan kemudahan siswa dalam memamahi materi pelajaran sehingga hal tersebut 
meningkatkan kemampuan menulis teks prosedur menjadi lebih optimal. Melalui penggunaan Google Classroom membuat proses pembelajaran menjadi lebih menarik, proses belajar siswa menjadi lebih interaktif, jumlah waktu belajar mengajar dapat dikurangi, kualitas belajar siswa dapat ditingkatkan, dan proses belajar dapat terjadi di mana saja dan kapan saja sehingga kemampuan menulis teks prosedur siswa dapat meningkat dengan baik.

Hasil penelitian ini sejalan dengan penelitian Budianti (2018) yang menunjukkan kemampuan menerapkan aspek struktur dalam menulis teks prosedur siswa dikategorikan sangat mampu dengan skor 3,75, dengan rincian siswa yang berkemampuan sangat mampu mencapai $75,5 \%, 24,5 \%$ siswa yang berkemampuan mampu, $0 \%$ siswa yang berkemampuan cukup mampu $0 \%$, dan $0 \%$ siswa yang berkemampuan kurang mampu. Kemampuan menulis teks prosedur berkategori sangat mampu dengan skor 3,69. Dari hasil penelitian ini disarankan kepada guru bahasa Indonesia di SMP Negeri 11 Kota Jambi agar guru lebih memperbanyak pengajaran pada kaidah kebahasaan karena bila semakin sulit maka harus semakin intensif dalam mengajarkan.

Berdasarkan hasil penelitian pada siswa kelas XI IPS A di SMA Negeri 6 Kota Bengkulu terdapat perbedaan yang signifikan antara sebelum dan sesudah menggunakan media Google Classroom. Hal ini dapat dilihat bahwa nilai yang diperoleh pada signifikan (2-tailed) dari nilai sebelum (pretes) dan sesudah (posttest) lebih kecil dari ketentuan uji statistik berarti menunjukkan data terdapat perbedaan yang signifikan. Berdasarkan uji $t$ hasil analisis menyatakan bahwa terdapat perbedaan kemampuan menulis teks prosedur sebelum dan sesudah menggunakan media Google Classroom siswa kelas XI IPS SMA Negeri 6 Kota Bengkulu. Hal ini terlihat dengan nilai $t$ hitung lebih kecil $(-20,858)$ dari nilai $t$ tabel $(-2.03)$. Hal ini mengakibatkan Ho ditolak dan Ha diterima, artinya adalah pembelajaran menulis teks prosedur dengan menggunakan media Google Classroom terdapat perbedaan atau berpengaruh terhadap hasil belajar siswa kelas XI IPS A di SMA Negeri 6 Kota Bengkulu.

Penelitian ini juga sejalan dengan penelitian yang dilakukan oleh Soleh (2021). Hasil penelitiannya menunjukkan bahwa penggunaan model pembelajaran Project Based Learning melalui Google Classroom mampu meningkatkan kemaampuan menulis teks prosedur siswa. Kemudian, dalam penelitian yang dilakukan oleh penulis, berdasarkan respons siswa terhadap penggunaan Google Classroom sangat baik dan diperoleh data bahwa Google Classroom sangat berguna dalam proses pembelajaran menulis teks prosedur. Hal ini dibuktikan dengan nilai siswa yang diperoleh setelah digunakannya Google Classroom sebesar 35,37 dengan kategori sangat tinggi. Berdasarkan hasil wawancara dengan salah satu siswa juga memberikan penjelasan bahwa dengan penggunaan Google Classroom dapat melihat dan membuka materi maupun tugas-tugas yang sudah diunggah oleh guru. Dalam penelitian ini, dapat dikatakan bahwa Google Classroom dapat meningkatkan kemampuan menulis teks prosedur.

Penggunaan Google Classroom ini dapat memudahkan siswa untuk menyimpan dokumen seperti materi maupun tugas penting yang dikirim melalui Google Classroom, sehingga jika siswa belum sempat untuk mencetak dokumen yang diperlukan, dan mereka dapat mengakses terlebih dahulu melalui Classroomnya masing-masing. Siswa juga dimudahkan untuk memperoleh pengumuman yang diberikan oleh guru secara cepat (real time) sehingga menjadi efektif dan efisien dari 


\section{Jon Kenedi, Gumono, Suryadi}

Perbedaan Kemampuan Menulis Teks Prosedur Sebelum dan Sesudah Menggunakan Media Google Classroom Siswa Kelas XI SMA Negeri 6 Bengkulu

segi waktu. Selain itu juga, siswa juga dapat melihat nilainya secara langsung setelah dikoreksi. Hal inilah yang membuat siswa termotivasi dalam pembelajaran karena tugas yang diberikan bisa tiap saat diubah jika masih ada yang kurang, terlebih lagi mereka dapat mengetahui kapan deadline dari tugas yang diberikan. Selain itu, mereka tidak perlu menggunakan kertas untuk mengumpulkan tugas-tugasnya.

Menurut Venkatesh dkk. dalam Afrianti (2018), sebuah sistem yang dibangun dalam Google Classroom dapat membantu memperoleh keuntungan atau kemudahan dalam bekerja. Hal ini menunjukkan bahwa siswa dalam melakukan proses pembelajaran yang dilakukan secara daring lebih meningkatkan kemampuan menulis teks prosedur yang berkaitan dengan penampilan, cara kerja maupun fasilitas yang diberikan oleh Google Classroom untuk penggunanya seperti pemberian materi maupun penilaian (assessment). Oleh karena itu, dengan penggunaan Google Classroom dapat meningkatkan kemamampuan siswa dalam belajar.

\section{Simpulan dan Saran}

Berdasarkan hasil penelitian dapat disimpulkan bahwa:

1. Kemampuan menulis teks prosedur siswa sebelum menggunakan Google Classroom sebesar 25,14 dengan kategori sangat tinggi.

3. Kemampuan menulis teks prosedur siswa sesudah menggunakan Google Classroom sebesar 35,37 dengan kategori sangat tinggi.

4. Berdasarkan uji $\mathrm{t}$ hasil analisis menyatakan bahwa terdapat perbedaan kemampuan menulis teks prosedur sebelum dan sesudah menggunakan media Google Classroom siswa kelas XI IPS SMA Negeri 6 Kota Bengkulu, dilihat nilai yang diperoleh pada signifikan (2-tailed) yaitu sebesar 0,00 dan terlihat nilai t hitung lebih kecil $(-20,858)$ dari nilai t tabel $(-2.03)$. Kemampuan menulis teks prosedur sebelum menggunakan Google Classroom sebesar 25,14 dan sesudah menggunakan google classroom sebesar 35,37.

Berdasarkan hasil penelitian ini, perlu kiranya peneliti memberikan beberapa saran sebagai berikut:

1. Bagi guru bahasa Indonesia untuk menggunakan media Google Classroom tersebut pada pembelajaran selanjutnya walaupun kondisi telah membaik dari pandemi Covid-19.

2. Bagi kepada sekolah, pembelajaran Google Classroom hendaknya direncanakan oleh para guru dengan baik dan dilakukan dengan pengelolaan waktu yang tepat sehingga pembelajaran dapat dilaksanakan sesuai yang diharapkan.

3. Bagi peneliti lanjutan diharapkan media Google Classroom dapat diteliti pada sekolah yang berbeda atau dapat diujikan pada kompetensi dasar lainnya. 
Jon Kenedi, Gumono, Suryadi

Perbedaan Kemampuan Menulis Teks Prosedur Sebelum dan Sesudah Menggunakan Media

Google Classroom Siswa Kelas XI SMA Negeri 6 Bengkulu

\section{Daftar Pustaka}

Afrianti, W. E. (2018). Penerapan Google Classroom Dalam Pembelajaran Akuntansi (Studi pada Program Studi Akuntansi Universitas Islam Indonesia). Skripsi. Yogyakarta: Fakultas Ekonomi Universitas Islam Indonesia Yogyakarta. https://dspace.uii.ac.id/bitstream/handle/123456789/6173/SKRIPSI.pdf?sequen $\mathrm{ce}=1$

Amrolani, A., Muslihah, N. N., \& Noermanzah, N. (2014). Peningkatan kemampuan menulis karangan deskripsi melalui teknik imajinasi siswa kelas IV SD Negeri 51 Lubuklinggau. Jurnal Perspektif Pendidikan, 8(1), 1-15, https://www.ojs.stkippgri-lubuklinggau.ac.id/index.php/JPP/article/view/447

Budianti, N. dkk. (2018). Kemampuan Menulis Teks Prosedur Siswa Kelas VII D SMP Negeri 11 Kota Jambi. Skripsi. Jambi: Universitas Jambi.

Ernawati. (2018). Pengaruh Penggunan aplikasi Google Classroom terhadap Kualitas Pembelaran dan Hasil Belajar Siswa pada Mata Pelajaran Ekonomi Kelas XI di MAN 1 Kota Tangerang Selatan. Skripsi Jurusan Ilmu Pengetahuan Sosial Fakultas Ilmu Tarbiyah dan Keguruan Universitas Islam Negeri Syarif Hiodayatullah. Jakarta: Universitas Islam Negeri Syarif Hiodayatullah.

Hapsari, S. A., \& Pamungkas, H. (2019). Pemanfaatan Google Classroom sebagai Media Pembelajaran Online di Universitas Dian Nuswantoro. WACANA: Jurnal IImiah IImu Komunikasi, 18(2). doi:10.32509/wacana.v18i2.924

Hikmatiar, H., Sulisworo, D., \& Wahyuni, M. E. (2020). Pemanfaatan Learning Manegement System Berbasis Google Classroom dalam Pembelajaran. Jurnal Pendidikan Fisika, 8(1). doi:10.26618/jpf.v8i1.3019

Kosasih, E. (2014). Jenis-Jenis Teks (Analisis Fungsi, Struktur, dan Kaidah serta Langkah Penulisannya). Bandung: Yrama Widya.

Nafiah, N. (2020). Penerapan Penerapan Manajemen Pembelajaran berbasis Daring dengan Menggunakan Aplikasi google Classroom untuk meningkatkan Kemampuan Mahasiswa dalam Membuat Perangkat Pembelajaran. Education and Human Development Journal, 5(1), 9-23. doi:10.33086/ehdj.v5i1.1486

Nurgiyantoro, B. (2012). Penilaian Pembelajaran Bahasa. Yogyakarta: BPFE.

Nuryaningsih, W. D. (2021). Penerapan Model Discovery Learning Berkolaborasi Google Classroom dan WhatsApp Group untuk Meningkatkan Kompetensi Siswa dalam Menulis Teks Eksplanasi. Jurnal Paedagogy, 8(2), 159. doi:10.33394/jp.v8i2.3540

Permata, A., \& Bhakti, Y. B. (2020). Keefektifan Virtual Class dengan Google Classroom dalam Pembelajaran Fisika Dimasa Pandemi Covid-19. JIPFRI 
Jon Kenedi, Gumono, Suryadi

Perbedaan Kemampuan Menulis Teks Prosedur Sebelum dan Sesudah Menggunakan Media

Google Classroom Siswa Kelas XI SMA Negeri 6 Bengkulu

(Jurnal Inovasi Pendidikan Fisika Dan Riset IImiah), 4(1), 27-33. doi:10.30599/jipfri.v4i1.669

Pradana. (2017). Pengaruh Penerapan Tools Google Clasroom pada Model Pembelajaran Project Based Learning Terhadap Hasil Belajar Siswa. IT-Edu : Jurnal Information Technology and Education, 2(1), https://jurnalmahasiswa.unesa.ac.id/index.php/it-edu/article/view/20527

Soleh, D. (2021). Penggunaan Model Pembelajaran Project Based Learning melalui Google Classroom dalam Pembelajaran Menulis Teks Prosedur. Ideguru: Jurnal Karya IImiah Guru, 6(2), 137-143. doi:10.51169/ideguru.v6i2.239

Susetyo, S., \& Noermanzah, N. (2020). Kemampuan dan Kesulitan Mahasiswa Program Studi Pendidikan Bahasa Indonesia Universitas Bengkulu dalam Menulis Proposal Penelitian Skripsi. Silampari Bisa: Jurnal Penelitian Pendidikan Bahasa Indonesia, Daerah, dan Asing, 3(2), 182-201. doi:10.31540/silamparibisa.v3i2.1071

Tarigan, H. G. (2008). Menulis Sebagai Sesuatu Keterampilan Bahasa. Bandung: Angkasa Bandung.

Silampari Bisa: Jurnal Penelitian Pendidikan Bahasa Indonesia, Daerah, dan Asing Vol. 4, No. 1, 2021 